\title{
LIIKETALOUSINNOVAATIOIDEN KEKSIMINEN ON MYÖS KOGNITIIVINEN PROSESSI
}

\begin{abstract}
Luovuus ja keksiminen on perinteisesti liitetty tieteeseen, teknologiaan ja taiteeseen. Kuitenkin myös liiketaloudellisessa toimintaympäristössä on käyttöä luovuudelle. Siksi taloutta kutsutaan nykyisin innovaatiotaloudeksi. Informaatiolla ja tiedolla ei kuitenkaan ole merkitystä, jos niitä ei osata soveltaa innovaatioprosessissa. Innovatiiviset yritykset ja innovatiiviset henkilöt keskittyvät enemmän tulevaisuuteen kuin menneeseen ja tällöin on sitouduttu luopumaan vanhoista uskomuksista, teorioista ja toimintatavoista.
\end{abstract}

\section{JYRKI SUOMALA, VESATAATILA, REIJO SILTALA \& SOILI KESKINEN}

Y ksilöiltä ja organisaatioilta edellytetään tietoyhteiskunnassa kekseliäisyyttä. Kyky oppia ja tuottaa tietoa on olennainen osa työelämää yhteiskunnan kaikilla sektoreilla. Tiedon ja luovuuden kombinaatio on erityisen tärkeää yrityksille, koska uusi tieto ja luovuus johtavat innovaatioihin (Ståhle \& Grönroos 1999; Sveiby 1997). Innovaatioilla puolestaan on keskeinen rooli yritysten toiminnassa, sillä niiden avulla ne pystyvät kilpailemaan globaaleilla markkinoilla (Kenney 2001). Nopeasti muuttuvassa markkinatilanteessa innovaatioihin kykenevä organisaatio on etulyöntiasemassa. Kyvystä tuottaa innovaatioita on tullut ratkaiseva kilpailutekijä taloudessa (Johnston \& Bate 2003). Perinteisesti liiketaloudessa on korostettu työn, pääoman ja muun aineellisen omaisuuden merkitystä. Tietoyhteiskunnassa näiden materiaalisten tekijöiden rinnalle nostettiin informaatio ja tieto.

Luovuus ja keksiminen on perinteisesti liitetty tieteeseen, teknologiaan ja taiteeseen. Nyt kuitenkin myös liiketaloudellisessa toimintaympäristössä luovuudella on käyttöä. Tämän vuoksi taloutta kutsutaan nykyisin innovaatiotaloudeksi. Informaatiolla ja tiedolla ei kuitenkaan ole merkitystä, jos niitä ei osata soveltaa innovaatioprosessissa. Innovatiiviset yritykset ja innovatiiviset henkilöt keskittyvät enemmän tulevaisuuteen kuin menneeseen ja tällöin on sitouduttu luopu- maan vanhoista uskomuksista, teorioista ja toimintatavoista.

Suomen virallinen visio nojaa myös innovaatioihin. Keskeisenä ongelmana Suomessa on nähty se, että teknologiset innovaatiot johtavat harvoin kaupalliseen menestykseen (Koski, Rouvinen \& Ylä-Anttila 2002). Humaania, taloudellista ja teknologista kehitystä ei ole osattu yhdistää oikealla tavalla innovaatioiden tuottamiseen (Tuomi 2002).

Innovaatioiden kaupallistaminen on taito, johon voidaan vaikuttaa esimerkiksi koulutuksen avulla. Jotta koulutuksen avulla voitaisiin tukea opiskelijoiden kehitystä niin, että heistä mahdollisimman monesta tulisi taloudellisten innovaatioiden tuottajia, innovaatioiden synnystä täytyy muodostaa käsitys. Tässä kirjallisuuteen pohjautuvassa artikkelissa tarkastelemme liiketalousinnovaatioiden keksimisprosessia kognitiivisesta näkökulmasta. Kaupallisen koulutuksen organisoinnissa sekä yliopistoissa että ammattikorkeakouluissa innovaatioiden keksimiseen pitäisi kiinnittää enemmän huomioita.

\section{LIIKETALOUSINNOVAATION MONTA ULOTTUVUUTTA}

Innovaationa pidetään yleensä keksintöä, jolla on käytännöllistä sovellusarvoa. Keksinnöllä vii- 
tataan yleensä teknologiseen tuotteeseen. Sovellusarvon miniminä voidaan pitää sitä, että keksintö toimii. Tällöin voidaan jo keksinnön prototyyppiä pitää innovaationa. Innovaatioiden merkityksen kasvaessa tällainen perinteinen innovaatiokäsitys on saanut useita laajennuksia. Tarkastelemme seuraavassa näitä laajennuksia ja luvun lopussa palaamme liiketalousinnovaation käsitteeseen.

Koska innovaatioilla on tärkeä merkitys tietoyhteiskunnassa ja innovaatiotaloudessa, on tullut tarpeelliseksi tarkastella innovaatiota produktin lisäksi prosessina. Organisaatioissa pyritään luomaan suotuisat olosuhteet sille, että syntyisi innovaatioita. Tällöin on välttämätöntä kiinnittää huomio innovaatioprosessiin. Näin innovaatiolla on alettu tarkoittamaan keksinnön prototyypin lisäksi keksimisprosessia. Tässä käytetään termejä innovaation keksiminen ja innovaatio, jolloin innovaation keksimisellä viitataan prosessiin, jonka seurauksena innovaatio muodostuu.

Perinteinen innovaationäkemys pitää sisällään vain tuoteinnovaatiot. Nykyisin on kuitenkin havaittu, että tarvitaan keksintöjä, jotka liittyvät ihmisten toimintatapojen muutoksiin ja palveluihin. Onkin tarpeen sisällyttää innovaation käsitteeseen tuoteinnovaatioiden lisäksi palveluinnovaatiot ja toimintatapainnovaatiot.

Innovaatiota voidaan tarkastella sisällön, laajuuden ja uutuusarvon perusteella. Innovaation sisällöllinen ulottuvuus tarkoittaa innovaation kohdetta. Tuoteinnovaatio voi olla kokonaan uusi tuote tai oleellinen parannus olemassa olevaan tuotteeseen. Esimerkiksi matkapuhelin on kokonaan uusi tuote. Sen sijaan Navi-monitoiminäppäimen keksiminen vuonna 1995 kännykkään oli teknologisesti pieni ja yksinkertainen parannus, mutta oleellinen ja Nokialle taloudellisesti kannattava innovaatio. Sitä on käyttänyt yli 300 miljoonaa kuluttajaa ympäri maailman. Toiminnallinen innovaatio on uusi toimintatapa. Toimintatavan muutos voi liittyä organisaation hallintouudistukseen, tuotteen uuteen valmistustapaan tai koulutuksen uudelleen organisointiin. Palveluinnovaation kohteena voi olla uusi tapa palvella asiakkaita. Esimerkiksi Pizzan kotijakelu on jossain vaiheessa ollut tällainen palveluinnovaatio.

Innovaation laajuutta voidaan tarkastella jatkumolla suppea - laaja. Suppea innovaatio on usein pieni kehitysaskel jo olemassa olevaan tuotteeseen, toimintatapaan tai palveluun. Laaja innovaatio kohdistuu kokonaiseen tuoteperheen, koko organisaatioiden toimintatapaan tai uuteen palvelukonseptiin. Tekstiviestitoiminto oli periaatteessa hyvin suppea teknologinen keksintö, mutta sen merkitys taloudellisesta näkökulmasta oli suuri. Sillä on ollut myös laajoja sosiaalisia vaikutuksia ihmisten tapaan kommunikoida keskenään.

Kokonaan uuden toimintatavan keksimistä voidaan pitää laajana innovaationa. Kaupalliselta puolelta voidaan mainita verkostomarkkinointi ja varhaiskasvatuksen puolelta esimerkiksi Reggio Emiliaan perustettu varhaiskasvatusjärjestelmä toisen maailman sodan jälkeen. Reggio Emiliassa varhaiskasvatus organisoitiin tilojen käyttöä myöten täysin uudella, radikaalilla tavalla.

Innovaation uutuusulottuvuutta voidaan tarkastella historiallisesta ja käsitteellisen muutoksen näkökulmasta. Historiallisessa mielessä innovaation aitoa alkuperäisyyttä on usein vaikea todentaa. Dasgupta (1996) korostaa, että innovaatio on aina sidoksissa jo aikaisemmin keksittyihin artefakteihin ja artefakti verkostoihin. Grupp ja Maital (2001) luokittelevat tuoteinnovaatiot kolmeen ryhmään niiden uutuusasteen perusteella. Inkrementaalinen innovaatio tarkoittaa uutta kehitysversiota olemassaolevasta tuotteesta. Standardi innovaatio tarkoittaa, että vanhaan tuotteeseen lisätään jokin uusi ominaisuus ja radikaalilla innovaatiolla tarkoitetaan selkeästi uutta tuotetta. Samaa luokittelua voidaan soveltaa toimintatapa- ja palveluinnovaatioihin. Tällöin inkrementaalisella innovaatiolla tarkoitetaan sitä, että organisaatio kehittää olemassaolevaa toimintatapaa paremmaksi. Esimerkiksi henkilöstökoulutuksessa siirrytään formaalista johtamistavasta informaaliin johtamistapaan. Standardiinnovaatio voisi tarkoittaa sitä, että henkilöstökoulutuksen sisältöä kehitetään oleellisesti uudella tavalla ja radikaali-innovaatio tässä yhteydessä tarkoittaisi sitä, että koko organisaation henkilöstön kehittäminen integroitaisiin organisaation tahtotilaan ja se saisi kokonaan uuden muodon.

Uutuusulottuvuutta voidaan lisäksi tarkastella käsitteellisen muutoksen näkökulmasta. Keksimisessä käsitteellinen muutos tapahtuu useimmiten uusien käsitteiden muodostamisen tai uudelleenluokittelun avulla (Thagard 1999). Inkrementaalinen ja standardi-innovaatio eivät yleensä edellytä sitä, että innovaatiolle täytyisi keksiä kokonaan oma nimi. Riittää, kun olemassaolevaan tuotteeseen tai toimintatapaan lisätään uusia 
ominaisuuksia. Sen sijaan radikaali innovaatio on usein luonteeltaan sellainen, että sitä ei voi enää määritellä tunnetun käsiteluokituksen avulla, vaan sille pitää keksiä joko kokonaan uusi luokka tai sitten se pitää siirtää toisen käsiteryhmän alle.

Asioista ei kuitenkaan muodosteta mielikuvia vain niiden systemaattisen luokkarakenteen perusteella. Monet esineet ja laitteet tunnistetaan käsiteprototyyppien avulla. Käsiteprototyypit mielletään esineen muuttumattomiksi piirteiksi ja ne auttavat määrittelemään käsitteen. Tällöin innovaatio ei välttämättä ole kovinkaan paljon erilainen kuin vanha tuote ulkoiselta olemukseltaan. Sen sijaan innovaatiossa on muutettu yhtä tai useampaa yleisesti muuttumattomana pidettyä piirrettä. Esimerkiksi filmikamera ja digitaalikamera eivät eroa ulkonaisesti kovin paljoa. Sen sijaan digitaalikameraa ei enää määritä aiemmin kameraan keskeisesti kuulunut osa filmi, vaan muistikortti (Markman \& Moreau 2001). Näin kameraa aiemmin määritellyt ominaisuus on muuttunut digitaalikamerassa ja sitä voidaan pitää radikaalina innovaationa. Mikä esimerkiksi määrittää polkupyörää? Kysyttäessä tätä asiaa ihmisiltä, hyvin pian tulee esille pyörän ketjut. Ketjuja pidetään polkupyörän yhtenä muuttumattomana piirteenä. Englannissa on kuitenkin jo keksitty polkupyörän prototyyppi, jossa ei ole ketjuja, vaan kardaaniakseli. Tätä voitaneen pitää radikaalina innovaationa, vaikka pyörä ulkoisesti ei juurikaan poikkea ketjuilla varustetusta polkupyörästä.

Sisällytämme innovaation käsitteeseen tuote, palvelu ja toimintatapainnovaatiot. Innovaatio on siis tuotteeseen, palveluun tai toimintatapaan liittyvä keksintö, jolla on sovellusarvoa. Viittaamme innovaation keksimisprosessiin termillä innovaation keksiminen. Mutta miksi sitten käytämme termiä liiketalousinnovaatio?

Liiketalousinnovaatiolla tarkoitetaan innovaatiota, joka on osoittautunut liiketataloudellisesti kannattaviksi. Usein innovaation käsitteeseen liitetään tämä ulottuvuus, mutta käytännössä tällöin on usein kyse vasta innovaation ensimmäisestä sovelluksesta tai patentoinnista, vaikka liiketaloudellisen hyödyn saaminen on vielä epävarmaa. Esimerkiksi Stevens ja Burley (1997) ovat analysoineet innovaatioiden tuottamista teollisuusyrityksissä. Heidän mukaansa vain yksi 3000 innovaatioideasta johtaa taloudelliseen menestykseen. Myös Tuomi (2002) on huomauttanut, että innovaatio on innovaatio vasta sitten, kun se saa merkityksen jossain sosiaalisessa konteks- tissa. Tämä merkityksen anto on niin moninaista, ettei innovaation tehnyt henkilö tai ryhmä useinkaan kykene ennakoimaan sille myöhemmin annettuja merkityksiä. Liiketalousinnovaatiossa uusi tuote, palvelu tai toimintatapa on osoittautunut markkinoilla siinä määrin merkitykselliseksi, että asiakkaat haluavat ostaa tuotetta. Tällä tavoin liiketalousinnovaatio on uutuus, jonka avulla yritys saa lisäarvoa. Tämä on voinut tapahtua niin, että yritykseen on innovaation seurauksena saanut aikaisempaan verrattuna enemmän voittoa tai niin, että kustannuksia on voitu vähentää. Liiketalousinnovaatio on siis uutuus joka tuo lisäarvoa asiakkaille ja tätä kautta yritykselle (Haho 2002 ; Johnston \& Bate 2003; Ståhle, Sotarauta ja Pöyhonen 2004; Urabe 1988). Tämä uutuus voi olla uusi tuote, uusi palvelu tai uusi toimintatapa. Rajaamme näin tarkastelun ulkopuolelle uudet keksinnöt, prosessit ja toimintatavat, joilla ei ole merkitystä yrityksen liiketoiminnassa.

Liiketaloudellisesta innovaatiosta puhuttaessa on syytä mainita vielä liiketoimintaympäristöön liittyvä keskeinen asia. Nykyisin korostetaan, että yritysten tulisi suosia kokonaisvaltaisia strategisia innovaatiota. Strategisella innovaatiolla tarkoitetaan yrityksen liiketoimintastrategian muutosta niin, että yritys tämän uuden strategian seurauksena kykenee entistä paremmin luomaan lisäarvoa sekä asiakkaille että yritykselle (Johnston \& Bate 2003). Johnston ja Bate (2003) korostavat, ettei yksittäisellä innovaatiolla ole yritykselle merkitystä, ellei sitä kyetä integroimaan yrityksen innovatiiviseen yritysmalliin. Tuote-, palvelu- ja toimintatapainnovaation liiketaloudellinen merkitys on sidoksissa yrityksen kykyyn tuottaa strategisia innovaatioita.

\section{LIIKETALOUSINNOVAATION KEKSIMISPROSESSI}

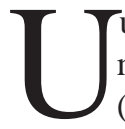
uden keksimistä voidaan pitää kaikkein merkittävimpämänä inhimillisenä kykynä (Klahr 2000,Thagard \& Croft 1999). Liiketalouskontekstissa keksiminen on tavoitteellista, monimutkaista ja älyllistä kapasiteettia vaativa prosessi. Sen edellytyksenä on päättely- ja ongelmanratkaisutaidot. Tässä päättelyssä toimija käyttää hyväkseen sisäisiä ja ulkoisia resursseja (Shirouzu, Miyake \& Masukawa 2002). Sisäiset resurssit viittaavat yksittäisen keksijän kognitiiviseen kapasiteettiin. Nämä sisäiset resurssit ovat muodostuneen yksilölle hänen henkilöhistorian- 
sa aikana vuorovaikutuksessa ympäristön kanssa. Ne ovat mentaalisia representaatioita, jotka sisältävät faktoja,kuvia, käsitteitä, uskomuksia, sääntöjä, teorioita, lakeja, hypoteeseja, metafyysisiä oletuksia, arvoja ja esimerkkejä asioista (Dasgupta 1996, Thagard 2000). Ulkoiset resurssit voidaan jakaa fysikaalisiin ja sosiaalisiin resurseihin.

Liiketalousinnovaation keksiminen on seurausta kompleksisesta prosessista, jossa yksilö on vuorovaikutuksessa sosiaalisen ja materiaalisen ympäristön kanssa. Keksiminen ei tapahdu tyhjiössä, vaan se tapahtuu tietyssä kulttuurisessa tilanteessa. Tässä tilanteessa keksimistä rajoittavat yksilön kognitiivinen kapasiteetti, sosiaaliset käytänteet ja työkalut. Näiden rajoitteiden uudelleen muokkaaminen, hyödyntäminen ja laajentaminen tuottavat uusia keksintöjä.

Kuvio 1 esittää liiketaloudellisen innovaation kompleksista luonnetta.

Liiketoimintakontekstissa keksimiseen sitoutuneet yksilöt osaavat tulkita sosiaalisia käytäntöjä ja ennakoida muutoksia näihin käytäntöihin. Samalla he ovat itse valmiita osallistumaan ja vaikuttamaan tämän muutoksen suuntaan. Kulttuuriset merkitykset ja käytänteet ovat aina lähtökohtana uuden keksimiselle. Tuomi (2002) korostaa, ettei innovaatioita synny elleivät toiset ihmiset arvosta keksintöä.

Liiketalousinnovaation keksimiseen vaikuttavat siis psykologiset, materiaaliset ja sosiaaliset tekijät. Keksiminen on osittain muutosta innovaattorin mielessä (Thagard 1999). Mieli vaikut- taa luontoon ajattelun välityksellä, kun innovaattori toteuttaa ideoitaan suunnittelemalla ja työkaluja sekä muita artefakteja käyttämällä. Luonto vaikuttaa mieleen havaintojen ja kokeista saadun uuden tiedon seurauksena. Nämä tulokset voivat vahvistaa innovaattorin käsityksiä tai sitten ne pakottavat muuttamaan suunnitelmaa. Kulttuuri vaikuttaa luontoon ylläpitämällä tavoitteita, organisaatioita ja verkostoja samoin kuin luonto vaikuttaa kulttuuriin, kun siitä saadaan tietoa, kun ihmiset ovat vuorovaikutuksessa kokeiden ja havaintojen välityksellä luonnon tai maailman kanssa. Samoin organisaatio ja lähiyhteisö antavat innovaattorille mahdollisuuden keksittyä innovaatioprosessiin. Innovaattorin mieli vaikuttaa organisaatioon ja ehkä koko kulttuuriin, jos innovaatiolla on merkitystä organisaation ja kulttuurin ihmisille.

,Ajattelutapamme on kehkeytynyt siinä kulttuurissa, jossa olemme eläneet. Kuitenkin innovaation näkökulmasta on oleellista kääntää katse ihmisen mieleen. Vaikka sosiaalisella verkostolla on ratkaisevan tärkeä merkitys uusien ideoiden syntymiselle, ilman ihmiselle tyypillistä kykyä luoda uusia representaatioita, ei synny uusia ideoita. Kulttuuri ja sen muutossuunta ovat lähtökohtana uusille innovaatioille.

On kuitenkin mielenkiintoinen kysymys, miksi vain harvat yksilöt ottavat ratkaisevan askeleen ja alkavat kehittää omia ideoitaan innovaatioiksi. Esimerkiksi vuonna 1970 Etelä-Kalifornian yliopistossa Los Angelesissa oli tuhansia opiskelijoita (Suomala 2005a). Uudeksi kulttuuriseksi käy-

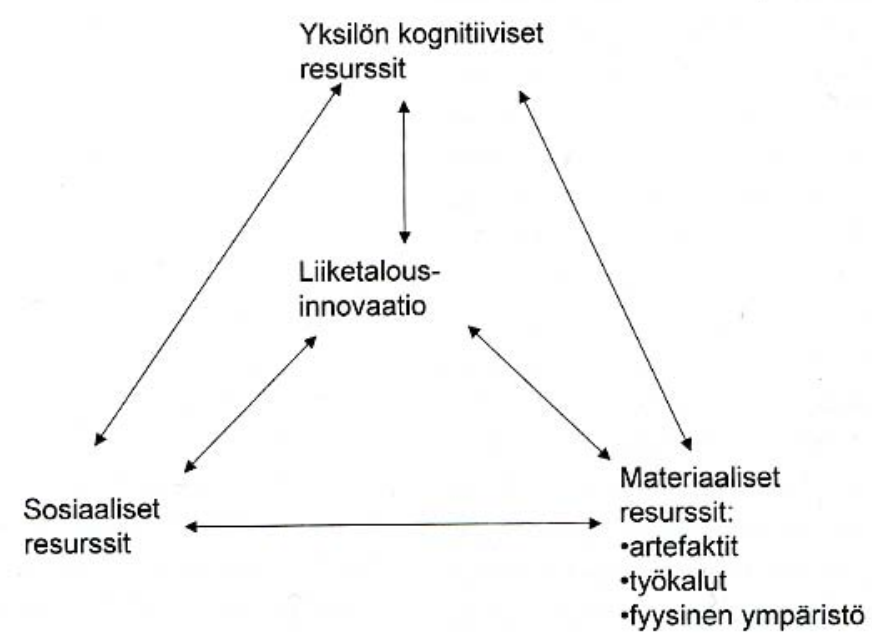


tännöksi oli muodostunut valokopioiden ottaminen. Opiskelijat jonottivat päivittäin valokopiokoneelle. Paul Orfalea oli myös usein näissä jonoissa. Hän oivalsi, että jonottaminen on tylsää ja hän keksi, että kopiointipalvelu on takuuvarmasti hyvä liiketoimintaidea. Samaan aikaan markkinoille tuli vallankumouksellinen Xerox-valokopiokone. Paul Orfalea otti pankista 5000 dollarin lainan, osti Xerox-valokopiokoneen ja perusti Isla Vistaan, Kaliforniassa sijaitsevan Santa Barbarbaran yliopiston viereen, "Kinko's Copy" -nimisen valokopiointiyrityksen. Yli kolme vuosikymmentä sitten kyseessä oli palveluinnovaatio. Vuosien kuluessa yrityksestä on kasvanut yli 25000 henkilön ja yli 1100 toimipaikan kansainvälinen suuryritys. Vuonna 2003 FeDex osti Kinkon 2,4 miljardin käteiskaupalla.

Kinko's-innovaatio syntyi tietyssä kulttuurisessa tilanteessa. Opiskelijoilla oli tarve saada valokopioita, heillä oli myös varaa ostaa niitä. Samoin Xerox-kopiokoneen keksiminen vaikutti Kinko's-palveluinnovaation syntyyn. Näitä kulttuurisia ja teknologisia tekijöitä analysoimalla ei kuitenkaan voida selittää sitä, miksi Kinko’s-copy syntyi. Ilman innovatiivista yksilöä - Paul Orfaleaa - sitä ei olisi syntynyt. Tämä siitä huolimatta, että myöhemmin vastaavia valokopiopalveluyrityksiä on syntynyt tuhansia. Vaikka keksimisen lähtökohtana ovat kulttuuriset käytänteet, ei ilman luovia yksilöitä ja heidän tapaansa hahmottaa sosiaalisia käytänteitä, voi syntyä innovaatioita.

Perinteisesti päättelyn ihanteena on pidetty muodollista logiikkaa, induktiota ja deduktiota. Tieteenfilosofiassa keksimisen ongelmaa pidettiin pitkään tieteen ulkopuolisena asiana. Tämä näkyy erityisesti Reichenbachin (1938) jaottelussa, jossa hän tekee jyrkän eron keksimisen logiikan ja todentamisen logiikan välillä. Samassa hengessä Popper (1989) toteaa, että kaikki tiedonvirikkeet voivat olla keksimisen ja oivalluksen lähteenä. Tieteellinen analyysi alkaa hänen mukaansa kuitenkin vasta silloin, kun tieteelliset argumentit on formuloitu eksplisiittiseen muotoon.

Jyrkkä jaottelu keksimisen ja loogisen analyysin välille on johtanut siihen, että keksimistä on usein pidetty hyvin mystisenä asiana. Käsitys keksijöistä yksin puurtavina hieman omituisina erakkoina, jotka sattumoisin kohtalon oikusta tekevät keksinnön, on varsin yleinen käsitys keksimisestä (Mayer 1995). Klassinen käsitys keksimisestä mystisenä, ei tutkittavana asiana on kui- tenkin nykyisin asetettu kyseenalaiseksi. On tapahtunut kognitiivinen käänne, jossa kognitieteestä ideoita ottamalla yritetään paremmin ymmärtää keksimisprosessia.

Kognitiotieteessä on havaittu, että keksijät todellisessa keksimistilanteessa käyttävät monipuolisesti erilaisia päättelytapoja, joista vain osa noudattaa muodollisen logiikan päättelysääntöjä (Thagard 1999). Ihmisen kapasiteetti käsitellä tilanteisiin liittyvää informaatiota loogisten prinsiippien perusteella ei riitä. Tilanteet sisältävät niin paljon toisiinsa kytkeytyviä asioita, että niiden kääntäminen deduktion tai induktion muotoon on vaikeaa. Keksiminen kognitiivisena prosessina tukeutuu mentaalisiin representaatioihin. Mentaalisten representaatioden käyttö on laajempaa, mihin muodollinen logiikka antaa mahdollisuuden (Thagard 2000). Muodollisen päättelyn malli ei kykene kuvaamaan todellista keksimisen prosessia tieteessä, teknologiassa eikä taloudellisessa innovoinnissa. Miten sitten keksimisen prosessia voisi kuvata?

Seuraavassa esitetään Thagardin (1999) kuvaus keksimisen prosessista. Malli pohjautuu kognitiotieteen tutkimustuloksiin tieteellisestä keksimisestä todellisissa keksimistilanteissa. Tässä mallia sovelletaan liiketalousinnovaatioiden keksimisen kuvaamiseen.

\section{KEKSIMISEN LÄHTÖKOHDAT}

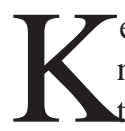

eksimisprosessin voi käynnistää käytännön tarve, älyllinen mielenkiinto, yllätys tai serindipisyys (Dasgupta 1996, Thagard 1999). Käynnistäminen voi ajallisesti olla pitkä tai lyhyt prosessi, sillä keksijällä saattaa olla mielessään idea, johon paneutumiseen ei kuitenkaan ole mahdollisuutta resurssien puutteen vuoksi. Toisaalta prosessi saatetaan käynnistää välittömästi esimerkiksi yrityksessä, jonka on pakko tehdä innovaatio.

Käytännön tarve on usein innovaatioiden lähtökohtana. Käytännön tarve voi syntyä yksilöllisesti tai yhteisöllisesti. Esimerkiksi monet informaatioteknologiset keksinnöt ovat syntyneet siitä, että sovelluksessa on ärsyttäviä piirteitä, joiden käyttäminen aiheuttaa turhautumista, jotka taitava ammattilainen haluaa korjata. Käytännön tarve voi olla myös tieteellisen keksimisen lähtökohtana, kun jonkin teknologisen tehtävän suorittaminen vaatii lisää tieteellistä tietoa siitä, kuinka maailma toimii (Thagard 1999). Liiketoiminnas- 
sa taloudelliset intressit luovat tarpeen keksiä uutta. Toisinaan on yksinkertaisesti pakko keksiä uutta, jotta toimintaa voidaan jatkaa. Tätä kuvaa hyvin vanha sanonta, jonka mukaan välttämättömyys on keksintöjen äiti (ks. Dasgupta 1996, 20).

Keksimisen käyttövoimana on usein myös älyllinen mielenkiinto. Tätä on pidetty lähtökohtana erityisesti tieteellisessä ja taiteellisessa keksimisessä. Älyllinen mielenkiinto onkin tärkeä lähtökohta innovaatioille, sillä kyse on toimimisesta epävarmuuden tilassa ja tämä puolestaan edellyttää motivaatiota ja sitoutumista pitkäaikaisiin prosesseihin. Ilman mielenkiintoa ja uteliaisuutta ei voi keksiä innovaatioita. Näiden prosessien tavoitteena ei ole välitön käytännöllinen hyöty, vaan ihmisten periaatteellinen halu tietää enemmän maailmasta ja sen toiminnasta.

Hyvä esimerkki älyllisestä mielenkiinnosta liiketalousinnovaation taustalla on aineettoman sumuvalkokankaan keksiminen (Suomala 2005b). Tampereen yliopiston tutkija Ismo Rakkolainen alkoi pohtia kesällä 2000 mahdollisuutta heijastaa kuvaa aineettomaan sumuun. Hän meni keskustelemaan ideasta professori Karri Palovuoren kanssa ja tämän 15 minuutin keskustelun aikana idea aineettomasta sumuvalkokankaasta kiteytyi. Idea syntyi akateemisesta mielenkiinnosta ja alunperin tarkoituksena ei ollut perustaa yritystä idean varaan. Nykyisin keksinnön ympärille on kuitenkin perustettu menestyvä yritys FogScreen.

Tuomi (2002) kuvaa Linuxin syntyhistoriaa ja sitä, miten idea on syntynyt hakkeriyhteisön kiinnostuksesta kehittää avointa lähdekoodia paremmaksi. Kyse ei alunperin ole ollut liiketaloudellisen voiton tavoittelusta, vaikka nykyisin Linuxilla on myös liiketaloudellista merkitystä. Pitkällä aikavälillä monilla tieteellisillä keksinnöillä on myös liiketaloudellista merkitystä, vaikka toiminnan motiivina ei useinkaan ole käytännön hyöty, vaan älyllinen mielenkiinto.

Yllätys saattaa myös käynnistää keksimisprosessin. Henkilö saattaa huomata asioita, jotka eivät sovi yhteen hänen käsityksensä kanssa. Tällöin tulee tarve selvittää tämä havainto. Tällainen yllättävä havainto käynnistää usein ns. abduktiivisen päättelyprosessin, jossa etsitään selitystä yllättävälle havainnolle tai tapahtumalle. Yllätys on hyvin subjektiivinen kokemus ja on ilmeistä, että luovat ihmiset kykenevät tekemään yllättäviä havaintoja tilanteessa, jossa suurin osa ihmisistä ei huomaa mitään erikoista.
Serendipisyys - onnekas oivallus - saattaa myös toimia keksimisprosessin käynnistäjänä tai johtaa suoraan innovaatioon. Serendipisyys on suomenkielinen käännös englanninkielisestä termistä “serendipity” (Salmi, Salmi \& Paukku 1998). Serindipisyys tapahtuu, kun keksijä löytää yllättäen asioita sattumalta. Serindipity saattaa johtaa suoraan innovaatioon, mutta usein se käynnistää innovaatioprosessin samalla tavoin kuin muutkin edellämainitut prosessit. Roberts (1998) erottaa toisistaan serindipisyyden ja pseudoserindipisyyden. Serindipisyys tarkoittaa, että sattumalta keksitään jotain, jota ei ole tietoisesti etsitty. Pseudoserindipisyys sitävastoin tarkoittaa sattumalta keksittyä keinoa päästä haluttuun tavoitteeseen.

Tarranauha on tuttu esimerkiksi lasten tarralenkkitossuista. Tarranauhan keksiminen perustui serendipisyyteen, sillä sen keksijä George deMaestral keksi sen huomattuaan, että sappiruoho tarrautuu hyvin voimakkaasti hänen vaatteisiinsa. Hänellä ei ollut aikomustakaan keksiä tällaista materiaalia, vaan hän keksi sen sattumalta, tehtyään edellä kuvatun havainnon.

Kumin vulkanisointia voidaan pitää pseudoserendipisyytenä. Charles Goodyerin tavoitteena oli ollut pitkään keksiä kumille hyödyllistä käyttöä. Hän tiputti vahingossa liedelle palan kumia, johon oli sekoitettu rikkiä. Vulkanisointimenetelmä tuli näin keksityksi vahingossa (Roberts 1996).

Käytännön tarve, älyllinen mielenkiinto, yllätys ja serindipisyys eivät ole toistensa vastakohtia ja keksimisprosessin saattaa käynnistää myös näiden kombinaatio. Monet tekevät käytännöllisiä innovaatioita uteliaisuudesta tai koska se tuottaa älyllistä tyydytystä. Masaru Ibuka, yksi SonyCorporation perustajista ja useiden kulutuselektroniikka tuotteiden keksijä on todennut, että hän keksii koska uusien asioiden tekeminen tuottaa hänelle suurta iloa ja sen avulla hän saa toteuttaa uteliaisuuttaan (Ks. Dasgupta 1996, 26).

\section{LÄHTÖKOHTA MUUTTUU TAVOITTEEKSI}

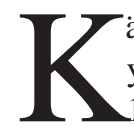

äytännön tarve, älyllinen mielenkiinto ja yllätys ovat mentaalisia tiloja (Dasgupta 1996). Myös serindipisyyteen liittyy mentaalisia tiloja. Nämä mentaaliset tilat kohdistuvat liiketaloudellisessa keksimisprosessissa tuote-, palvelu- tai toimintatapainnovaatioon. Voidaan olettaa, että näiden tilojen syntymisen 
ehtona on toimiminen innovatiivisessa ympäristössä. Mentaaliset tilat "kääntyvät” ongelmiksi, joiden rooli on hyvin keskeinen tieteellisen keksimisen prosessissa. Kognitiotieteessä on perinteisesti tutkittu päättelyä tilanteissa, joissa koehenkilöille on annettu kysymykset valmiina. Näistä tutkimuksista on saatu paljon tärkeää tietoa ajattelusta ja ongelmanratkaisusta. Niiden perusteella ei kuitenkaan voida selittää aitoa keksimisen prosessia, koska keskeinen osa tätä prosessia on ongelmien ja tavoitteiden muotoilu. Tuntemattoman asian tutkimiseksi täytyy muodostaa tutkimusongelmia. Thagardin (1999) mukaan tutkimusongelmat syntyvät mainittujen mentaalisten tilojen seurauksena.

Tutkimuskysymysten keksimisen jälkeen on suhteellisen yksinkertaista etsiä ratkaisua ongelmaan. Vaikka ei ole olemassa yleistä teoriaa siitä, miten relevantteja kysymyksiä luodaan (Thagard 1999), niiden rooli tieteellisessä päättelyssä ja keksimisessä on hyvin keskeinen. Koska tieteentekijät toimivat käytännössä avointen, kompleksisten ilmiöiden kanssa, ei voida loogisesti konstruoida kaikkia tilanteeseen liittyviä argumentteja ja lähteä arvioimaan niiden todenperäisyyttä loogisesti. Potentiaalisia mahdollisuuksia on aivan liikaa, jotta ne voitaisiin käydä systemaattisesti läpi. Sen sijaan kysymysten muotoilun avulla voidaan rajoittaa tutkimusprosessia niin, että keskitytään vain tutkimuksen kannalta keskeisten tekijöiden tutkimiseen. Tieteellisessä tutkimuksessa kysymykset esitetään usein muodossa:

I Miksi jokin ilmiö tapahtuu?

। Mikä jokin ilmiö on?

। Miten ilmiö a vaikuttaa ilmiöön b?

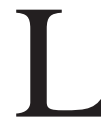

iiketaloudellisessa keksimisprosessissa keskeisenä tekijänä ovat liiketaloudelliset motiivit. Tällöin keksijän täytyy päättää, kuinka yhdistää mahdolliset toiminnot ja tavoitteet yhteen järkeväksi kokonaisuudeksi (Thagard 2000). Liiketalousinnovaation keksimisprosessia ohjaa sovellettavuus näkökohta. Kun tieteentekijät haluavat selvittää sitä, millainen jokin ilmiö on, liiketaloudellinen keksijä selvittää sitä, miten saisi otettua käyttöön uuden prosessin, toimintatavan tai valmistettua uuden tuotteen. Seuraavassa on esimerkkejä liiketaloudellisessa keksimistilanteessa esitetyistä kysymyksistä:

I Mitä pitää tehdä, että pääsisimme markkinaalueelle $\mathrm{X}$ ?

I Kuinka kehittää markkinoilla olevaa tuotetta paremmaksi?

I Kuinka valmistaa täysin uusi tuote?

I Kuinka y:tä voi soveltaa?

I Kuinka tuotantoprosessia voisi järkiperäistää?

Dasgupta (1996) korostaa, että teknologisten innovaatioiden keksimisprosessissa tuotetaan tavoitteita tutkimusongelmien sijasta. Voidaan olettaa, että myös liiketalouskontekstissa on kyse paremminkin tavoitteenasettelusta kuin ongelmanasettelusta. Tavoitteenasettelu on kuitenkin analoginen tieteellisen keksimisprosessin tutkimuskysymysten asettelun kanssa. Kyse on tehtävänjaosta ja ehkä ei ole mielekästä kognitiivisesta näkökulmasta erottaa niitä toisistaan.

Kuinka sitten relevantteja tavoitteita keksitään? Dasguptan (1996) mukaan teknologinen keksimisprosessi pohjautuu vain osittain fysiikkaan, kemiaan ja matematiikkaan. Hänen mukaansa teknologia liittyy artefaktien luomiseen, jolloin mukaan tulee tieteenalojen tiedon lisäksi kulttuuriset merkitykset ja sosiaaliset arvostukset. Kyse on luovasta prosessista, joka pohjautuu enemmän psykologiaan kuin luonnontieteisiin. Samalla tavoin tavoitteenasettelu liiketaloudellisessa kontekstissa ei ole palautettavissa taloustieteen teorioihin, vaan kyse on inhimillisen toiminnan kompleksisesta selittämisestä. Tavoitteenasettelu on vaativa kognitiivinen prosessi, jossa täytyisi löytyä sellaista, mitä ei vielä ole olemassa.

Sternbergin (1988) mukaan ongelmien tunnistaminen ja niiden muotoileminen käsiteltävällä tavalla ovat inhimillisen luovuuden keskeisimpiä piirteitä. Tavoiteet eivät ole olemassa, vaan ne täytyy keksiä ja tämän kyvyn suhteen yksilöt ilmeisesti eroavat toisistaan. Innovaattori katsoo maailmaa erilaisin silmin ja löytää tavoitteita sieltä, missä niitä muut eivät välttämättä näe.

Yritysmaailmassa toimivilla henkilöillä on hyvin paljon tietoa siitä, mihin suuntaan markkinat kehittyvät ja millainen on hyvä liiketoimintamalli. Mallia otetaan muista ja seminaareissa keskustellaan siitä, mihin suuntaan ollaan menossa. Voisi kuvitella, että tavoitteenasettelu on helppoa, koska informaatiota tulevista trendeistä on niin paljon saatavilla. Ammattilaisten keskuudessa olevat käsitykset eivät välttämättä johda innovaatioihin. Jaettu asiantuntijuus perustuu usein vakiintuneeseen tietoon ja toimintatapaan. Tämä tieto on luettavissa alan oppikirjoista ja se tieto jaetaan seminaareissa ja keskusteluissa. Innovaa- 
tio edellyttää ajatteluponnistusta yli tämän vakiintuneen jaetun asiantuntijuuden. Luovuus on vakiintuneen jaetun asiantuntijuuden ylittämistä ja uudistamista. Innovaatioprosessissa tuodaan tähän vakiintuneeseen tilanteeseen jotain uutta tai muutetaan koko tilannetta toiseksi.

On esimerkiksi arvokas asia, jos asiakkailta saadaan informaatiota siitä, millaisia tuotteita tai palveluksia he haluaisivat käyttää. Tällöin asiakkailta kysytään, mitä he haluavat ja sen jälkeen asetetaan toiminnan tavoitteeksi innovaatio, joka täyttää asiakkaiden ilmaiseman toiveen. Innovaatioiden kannalta tällainen menettely ei useinkaan tuota hyvää tulosta, vaikka sinänsä vuorovaikutus asiakkaiden kanssa on yrityksen yksi perustoimintoja. Asiakkaat arvioivat tulevaisuutta aikaisempien kokemustensa perusteella eivätkä kyselyissä useinkaan kykene tuottamaan ideoita uusista innovaatioista. Tämä näkyy esimerkiksi mobiilipalvelukyselyissä, joissa vastaajat pitävät tarpeellisina vain jo olemassaolevia mobiilipalveluja. Johnston ja Bate (2003) korostavat, että liiketalousinnovaatio piilee usein epäselvästi ilmaistavissa asiakastarpeissa. Artikuloimattomat tarpeet ovat sellaisia, joita asiakkaat eivät tiedosta eivätkä osaa täten tuoda ilmi haastatteluissa ja kyselyissä. Johnston ja Bate (2003) mainitsevat esimerkkeinä Sonyn Walkmanin, Dodge Caravanin ja Starbucksin grande latten. Nämä kaikki ovat tuotteita, joita asiakkaat eivät ole osanneet mainita haastatteluissa tai asiakaskyselyissä ennen niiden keksimistä. Esimerkiksi Walkmanissa yhdistyy kaksi ihmisille tärkeää arvoa, halu kuunnella musiikkia ja halu liikkua. Samalla tavoin voidaan puhua artikuloimattomasta logistiikasta ja markkinoinnista.

Tavoitteenasettelu on hyvin vaativa vaihe keksimisprosessissa. Tämä täytyy ottaa huomioon myös silloin, kun opiskelijat osallistuvat yritysten tutkimus- ja kehittämisprojekteihin. Usein ajatellaan, että tavoite on jotain, joka vain otetaan jostain valmiina. Pedagogisesti mielekkäässä keksimisprosessissa opiskelijalla on mahdollisuus osallistua tavoitteenasetteluprosessiin, sillä työelämä tarvitsee innovaattoreita, jotka osaavat asettaa tavoitteita luovalla tavalla.

\section{TAVOITTEENASETTELUSTA ETSINTÄPROSESSIIN}

Tavoitteenasettelu rajaa keksimisprosessia niin, että tarkoituksenmukaiset toimenpiteet voidaan tehdä. Toisinaan tavoitteenasettelun jälkeen liiketalousinnovaatio syntyy hyvin nopeasti. Usein keksintöön ei ole suoraan ratkaisua, vaan täytyy suorittaa etsintäprosessi. Etsintäprosessi on ongelma-avaruuden konstruointia. Tällöin innovaattori muodostaa mielikuvan lähtötilanteesta, tavoitellusta tilanteesta ja toimenpiteistä, jotka täytyy suorittaa innovaatioon pääsemiseksi. Innovaattorilla on mielessään mahdollisia hypoteettisia ratkaisuvaihtoehtoja ja näitä ratkaisuvaihtoehtoja testataan etsintäprosessin aikana.

Etsinnän käsite on tullut tunnetuksi ongelmanratkaisututkimuksessa Newellin ja Simonin (1972) myötä. Newell ja Simon (1972) pitävät ongelmaavaruuden käsitteen konstruoimista kriittisimpänä kohtana ongelmanratkaisussa. Thagard (1999) kuitenkin huomauttaa, että etsinnän käsite sopii huonosti tilanteisiin, joissa tutkimusongelmia ei ole annettu valmiina. Kriittisin vaihe prosessissa on ongelmien muotoilu, jonka jälkeen ongelmaavaruus voidaan konstruoida Newellin ja Simonin (1972) tarkoittamassa mielessä. Päinvastoin kuin useimpien kognitiotieteilijöiden malleissa (Klahr, Fay \& Dunbar 1993), Thagardin (1999) mukaan ongelmien löytäminen ei kuulu etsintäprosessiin. Sen on tapahduttava ennen, jotta ongelma-avaruutta voidaan rajata mielekkäällä tavalla etsintäprosessissa. Kysymysten muotoilun avulla keksimisprosessista tulee strukturoitu, vaikka lähtökohtana on ollut kompleksinen, usein äärettömän monta mahdollisuutta sisältävä tilanne. Kun järkevät tutkimuskysymykset on löydetty, on mahdollista suorittaa etsintä. Etsinnän seurauksena voi syntyä uusi teoria tai löytyä yllättävä uusi tulos, jonka seurauksena on tarpeen muodostaa uusia tutkimuskysymyksiä ja suorittaa uusia etsintäprosesseja.

Liiketalousinnovaatioiden keksimisprosessissa etsintä pitää sisällään liiketoiminnan kannalta keskeisten tekijöiden arviointia ja testausta. Käytännössä kyse on toimenpidesarjan konstruoinnista, jotta tavoitteeseen päästäisiin. Toimenpiteiden sisältö on sidoksissa innovaation sisältöön, laajuuteen ja uutuusarvoon. Etsinnän aikana voidaan kerätä tietoa tuotteen kestävyydestä, tuotantoprosessiin kuluvasta ajasta, markkinoinnista ja jakelusta. Etsintäprosessi saattaa johtaa liiketalousinnovaatioon tai mikäli etsinnän aikana löytyy jokin yllättävä käänne, keksimisprosessi palautuu takaisin ongelmanasetteluun.

Kuviossa 2 esitetään yhteenvetona malli liiketalousinnovaation keksimisestä. Kuvion mukaan 


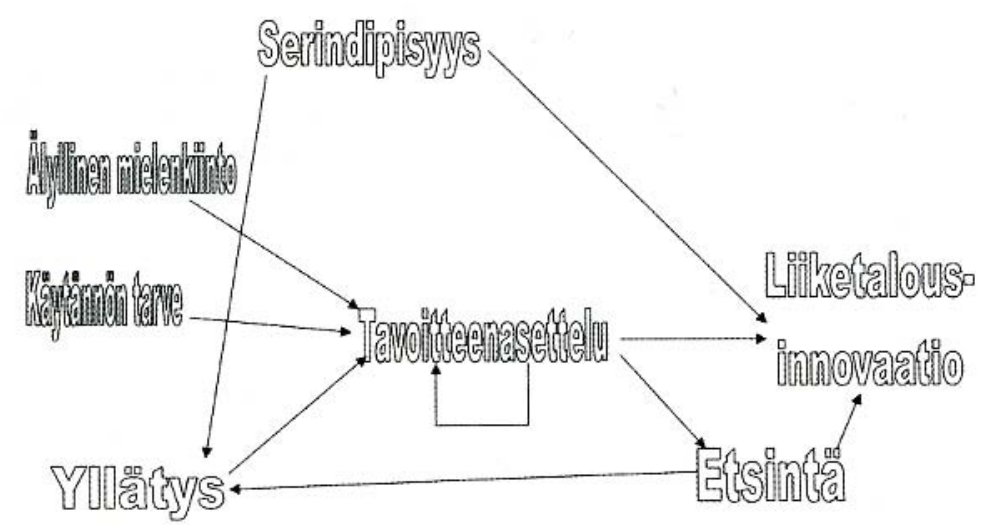

KUVIO 2. LIIKETALOUSINNOVATIO KOGNITIIVISENA PROSESSINA THAGARDIN (1999) TIETEELLISEN KEKSIMISEN MALLIA SOVELTAEN

tavoitteenasettelu saa alkunsa älyllisestä mielenkiinnosta, käytännön tarpeesta, yllätyksestä tai näiden kombinaatiosta. Yllätys saa alkunsa serendipisyydestä tai etsintäprosessin aikana tehdyistä havainnoista. Serendipisyys voi suoraan johtaa liiketalousinnovaatioon tai sitten prosessi voi palautua yllätyksen kautta tavoitteenasetteluun ja sitä kautta etsintään.

Kuvion tulkinnassa on tarpeen muistaa, että vaativassa innovaatioprosessissa yksilö tukeutuu ulkoisiin ja sisäisiin resursseihin. Usein idea syntyy ensin yksilön mielessä. Tämän jälkeen yksilö usein testaa ideaansa luotettavien henkilöiden kanssa ja varsinainen projekti lähtee liikkeelle siten, että idean keksinyt henkilö kerää ympärilleen sosiaalisia ja materiaalisia resursseja, jotta innovaation toteuttaminen olisi mahdollista (Taatila, Suomala, Siltala ja Keskinen, arvioitavana).

\section{POHDINTA}

Esitetty malli liiketalousinnovaatioden keksimisestä on johdettu Thagardin (1999) esittämästä tieteellisen keksimisen mallista. Thagard on tutkinut tieteellistä keksimistä kognitiotieteen näkökulmasta tarkastelemalla luonnontieteistä (1992), teknologiassa (Thagard \& Croft 1999) ja lääketieteessä (1999) tehtyjä keksintöjä.

Thagardin mukaan luonnontieteen ja lääketieteen keksinnöt sopivat hyvin tieteellisen keksimisen tutkimiseen, koska niiden avulla voidaa paikallistaa käsitteellinen muutokseen liittyvä päättelyprosessi. Näin voidaan kuvata sitä, miten yksittäiset tieteentekijät ovat aluksi joutuneet muuttamaan käsityksiään tutkimusprosessissa ilmaantuvien yllättävien havaintojen tai keskustelujen perusteella. Luonnontieteissä ja lääketieteessä, ainakin suurissa tieteellisissä läpimurroissa, saavutetaan ennemmin tai myöhemmin konsensus, koska ilmiöiden selitystä rajoittaa kausaalinen vuorovaikutus luonnon kanssa. Kaikki tutkimusprosesseissa saatu data on otettava vakavasti, vaikka uuden teorian yleinen hyväksyntä esimerkiksi lääketieteessä vie usein pitkän aikaa (Thagard 1999). Jos evidenssi sotii vallitsevaa teoriaa tai selitysmallia vastaan, selitetään tämä evidenssi lähes poikkeuksetta aluksi virheestä johtuvaksi (Dunbar 1999; Thagard 1999). Käsitteellisessä muutosprosessissa on siis runsaasti kitkatekijöitä.

Luonnontieteellisessä keksimisessä tavoitteena on selittää, millaisia ilmiöt ovat ja millaiset tekijät ilmiöihin vaikuttavat. Liiketalousinnovaatioiden keksimisessä tavoitteet ovat konkreettisia ja kohteena on uusi tuote, prosessi tai toimintatapa. Liiketalousinnovaation merkitys on lokaalinen, konteksti- ja aikasidonnainen. Sen sijaan luonnontieteellisen teorian tai lain merkitys on universaali ja periaatteessa yliajallinen. Luonnontieteellisessä keksimisessä kriittisin vaihe on tutkimusongelmien keksiminen, kun taas taloudellisen innovaation keksimisprosessissa kriittisin vaihe on tavoitteen asettaminen. Mainituista eroista huolimatta, kognitiivisesta näkökulmasta ei ole syytä olettaa, että keksimisprosessit eroaisivat toisistaan. Sekä tieteellinen keksiminen että liiketalousinnovaation keksiminen ovat tavoitteellisia ja rationaalisia prosesseja, jotka edellyttävät ajattelukykyä ja erityisesti mielikuvitusta. Keskeiseen rooliin nousee mielikuvitus.

Olemattoman teorian tai innovaation ajattele- 
minen vaatii mielikuvitusta. Lapset voivat helposti kuvitella mielessään vihreän lohikäärmeen tai keltaisen norsun. Samalla tavalla luova tieteentekijä pystyy kuvittelemaan, että on olemassa teoria tai selitysmalli, joka on parempi kuin tämän hetken teoria tai selitysmalli. Myös liiketaloudellinen innovaattori käyttää mielikuvitustaan ja kykenee kuvittelemaan mielessään liiketaloudellisesti kannattavan tuotteen, toimintatavan tai prosessin, jota ei vielä ole olemassa. Lapselle mielikuvituksen tuotteet ovat tosia sinänsä. Tieteentekijän pitää todistaa mielikuvituksensa tuote oikeaksi. Luonnontieteissä ja lääketieteessä evidenssi haetaan kokeiden tulosten perusteella. Millainen evidenssi tarvitaan liiketaloudellisen innovaation todistamiseksi?

Markkinat todistavat liiketalousinnovaation oikeaksi tai vääräksi. Markkinoiden logiikka on kompleksinen systeemi ja tämän kompleksisen systeemin logiikan ymmärtäminen käytännön tasolla on välttämätön edellytys taloudelliselle innovaatiolle. Tieteellinen koe ja sen tulkinta on analoginen sille moninaiselle tietojenkeruulle, joka liittyy taloudellisen keksimisprosessin etsintävaiheeseen.

Olemme tarkastelleet Thagardin mallia tieteellisestä keksimisestä ja rakentaneet sen pohjalta mallin (Kuvio 2) liiketalousinnovaatioiden keksimisprosessista. Olemme tarkastelleet keksimisprosessia tässä artikkelissa yksilön näkökulmasta. Nykyisin tieteellinen tutkimus (Thagard 1997; Wray 2002) organisoidaan ryhmätyönä. Samoin liiketaloudellisessa ympäristössä innovaatioprojektit tapahtuvat ryhmissä (Nonaka \& Takeuchi 1995). On kuitenkin tärkeää muistaa, että uuden keksiminen on ihmiselle ominainen kyky ja sen lähtökohtana on kykymme käyttää mielikuvitusta ja sen seurauksena ajatella sellaisia asioita, joita ei vielä ole olemassa. Tämä "kognitiivinen aparaatti” sijaitsee ihmisen pään sisällä. Ajattelu ja keksiminen on kuitenkin aina sidoksissa niihin sosiaalisiin ja fysikaalisiin resursseihin, joita keksijällä on käytettävissä keksimisprosessin aikana. Usein innovaation lähtökohtana, ainakin aloittavissa yrityksissä, on yksilö, joka keksii jonkin idean (Taatila, Suomala, Siltala \& Keskinen, arvioitavana). Tämän jälkeen yksilö tukeutuu niihin sosiaalisiin ja materiaalisiin resursseihin, joita hänellä on käytössään.

Mitä esitetty malli liiketalousinnovaatiosta merkitsee koulutuksen kannalta? Korkeakouluissa ja yliopistoissa koulutus on usein järjestetty sen tiedon varaan, joka on jo keksitty ja joka on asiantuntijoiden yhteistä omaisuutta. Tämän tiedon merkitystä ei tule vähätellä. Luovuuden kehittäminen liiketaloudellisessa ympäristössä edellyttää kuitenkin dynaamista lähestymistapaa olemassa olevaan asiantuntijatietoon. Tällöin on tarpeellista, että opiskelijat koulutuksen aikana saavat kosketuksen työelämään ja voivat työelämässä saada sellaisen roolin, jossa he voivat aktiivisesti osallistua innovaatioprosessien tavoitteenasetteluun. Tällöin oppimisen kohteena ei ole tieto, vaan tietoa käytetään välineenä, jotta voitaisiin luoda jotain uutta ja merkittävää.

\section{LÄHTEET}

Dasgupta, S. (1996) Technology and Creativity. Oxford University Press, New York.

Dunbar, K. (1999) How scientists build models in vivo science as a window on the scientific mind. Teoksessa L.Magnani, N.J. Nersessian ja P. Thagard (toim.) Model-Based Reasoning in Scientific Discovery (s. 85-99). Kluwer Academic/Plenum Publishers, New York.

Grupp, H. \& Maital, S. (2001) Managing New Product Development and Innovation. A Muctoeconomic Toolbox. Edward Elgar Publishing, Cheltenham.

Haho, P. (2002) Strategic and Operational Process Innovations in NPD Processes Applying Evolutionary Change Management. 4th International CINet 2002 Conference "Continuous Innovation in Business Processes and Networks", Espoo, September, 1518, 2002, 299-314.

Johnston, R.E. \& Bate, J.D. (2003) The power of strategy innovation. A new way of linking creativity and strategic planning to discover great business opportunies. AMACOM, New York.

Kenney, M. (2001) The temporal dynamics of knowledge creation in the information society. Teoksessa I. Nonaka and T. Nishiquchi (toim.) Knowledge Emergence, Social, Technical, and Evolutionary Dimensions of Knowledge Creation (s. 93-110). Oxford University Press, New York.

Klahr, D. (2000) Exploring Science. The Cognition and Development of Discovery Processes. The MIT Press, Cambridge, MA.

Klahr, D., Fay, A. \& Dunbar, K. (1993) Heuristics 
for scientific experimentation: A developmental study. Cognitive Psychology 25 (1), 111-146.

Koski, H., Rouvinen, P. \& Ylä-Anttila, P. (2002) Mitä "uudesta taloudesta” jäi. Edita.

Magnani, L. (1999) Model-Based Creative Abduction. Teoksessa L.Magnani, N.J. Nersessian ja P. Thagard (toim.) Model-Based Reasoning in Scientific Discovery (s. 219254). Kluwer Academic/Plenum Publishers, New York.

Markman, A.B. \& Moreau, C.P. (2001) Analogy and analogical comparison in choice. Teoksessa D. Gentner, K.J. Holyoak and B.N. Kokinov (toim.) The analogical Mind. Perspectives from Cognitive Science (s. 363-399). The MIT Press, Cambridge, MA.

Mayer. R.E. (1995) The search for insight: Grappling with gestalt psychology’s unanswered questions. Teoksessa R.J.Sternberg ja J.E. Davidson (toim.) The Nature of Insight (s. 3-32). MIT Press, Cambridge, MA.

Newell, A. \& Simon, H.A. (1972) Human problem solving. Prentice-Hall, Englewood Cliffs.

Nonaka, I. \& Takeuchi, H. (1995) The Knowledge-Creating Company. Oxford University Press, New York.

Reichenbach, H. (1938) Experience and Prediction. University of Chicago Press, Chicago.

Roberts, R.M. (1998) Sattuma tieteessä. Onnekkaitten oivallusten historiaa. Helsinki University Press.

Popper, K.R. (1989) Conjectures and refutations. $5^{\text {th }}$ revised and corrected edition. Routledge, New York.

Salmi, L., Salmi, H. \& Paukku, T. (1998) Suomentajan esipuhe. Teoksessa R.M. Roberts, Sattuma tieteessä (s.6). Helsinki University Press.

Shirouzu, H., Miyake, N. \& Masukawa, H. (2002) Cognitively active externalization for situated reflection. Cognitive Science 26, 469-501.

Sternberg, R.J. (1988). A Three-Facet Model of Creativity. Teoksessa R.J. Sternberg (toim.) The nature of Creativity (s. 101-119). Cambridge University Press, Cambridge, MA.

Stevens, G. A. \& Burley, J. (1997) 3000 raw ideas equals 1 commercial success! Research
Technology Management 40 (3), 16-27.

Suomala, J. (2005a). Paul Orfalean haastattelu 7.1.2005 Montecitossa. Julkaisematon.

Suomala, J. (2005b). Ismo Rakkolaisen haastattelu 24.1.2005 UCSB:ssä. Julkaisematon.

Ståhle, P. and Grönroos, M. (1999). Knowledge Management - tietopääoma yrityksen kilpailutekijänä. Ekonomia-sarja,WSOY.

Ståhle, P., Sotarauta, M. and Pöyhönen, A. (2004) Innovatiivisten ympäristöjen ja organisaatioiden johtaminen. Tulevaisuusvaliokunta, Teknologian arviointeja 19, Eduskunnan kanslian julkaisu 6/2004.

Sveiby, K. (1997). The New Organizational Wealth: Managing and Measuring Knowledge-Based Assets. Berrett-Koehler, San Francisco.

Taatila, V., Suomala, J., Siltala, R. \& Keskinen, S. (arvioitavana). Framework to study the social innovation networks. European Journal of Innovation Management.

Thagard, P. (1997). Collaborative knowledge. Nous 31, 242-261.

Thagard, P. (1999). How scientists explain disease. Princeton University Press, Princeton.

Thagard, P. (2000). Coherence in Thought and Action. The MIT Press, Cambridge, MA.

Thagard, P. \& Croft, D. (1999) Scientific discovery and technological innovation: Ulcers, dinosaur extinction, and the programming language Java. Teoksessa L.Magnani, N.J. Nersessian ja P. Thagard (toim.) ModelBased Reasoning in Scientific Discovery (s. 125-137). Kluwer Academic/Plenum Publishers: New York.

Tuomi, I. (2002) Networks of innovation. Change and meaning in the age of internet. Oxford University Press, New York.

Urabe, K. (1988) Innovation and the Japanese Management System. Teoksessa K. Urabe, J. Child and T. Kagono (Toim.) Innovation and Management, International Comparisons (s.3-25), De Gruyter \& Co: Berlin.

Wray, K.B. (2002) The epistemic significance of collaborative research. Philosophy of Science 69, 150-168.

Artikkeli saapui toimitukseen 17.10.2004. Se hyväksyttiin julkaistavaksi toimituskunnan kokouksessa 22.8.2005. 